\title{
ASPECTS STRUCTURELS ET FONCTIONNELS DE LA BIODIVERSITÉ DES PEUPLEMENTS DE POISSONS.
}

\author{
K. O. WINEMILLER
}

Department of Wildlife and Fisheries Sciences, Texas A\&M University, College Station, Texas 77843-2258, USA.

\section{RÉSUMÉ (traduit par les éditeurs)}

Cet article passe brièvement en revue les relations existant entre la biodiversité des peuplements de poissons et leur fonctionnement écologique. La biodiversité et la structure des peuplements peuvent être décrites, à l'échelle locale, en termes (1) de diversité phylogénétique, (2) de structure des populations, (3) de stratégies démographiques, (4) de diversité morphologique, (5) et de diversité trophique. Un défi majeur est de déterminer les relations qui existent entre la structure des populations et des peuplements et le fonctionnement des peuplements et des écosystèmes. La structure phylogénétique d'un peuplement résulte de l'interaction entre colonisation, extinction et évolution. En dépit du fait que ces facteurs opèrent sur une vaste gamme d'échelles spatiales et temporelles, de grands progrès ont été réalisés dans la modélisation des processus qui sont à la base de la structure génétique et phylogénétique des populations et des peuplements. Les modes de reproduction des poissons sont très variés, et la définition de guildes de reproduction et de stratégies démographiques permet de poser le cadre dans lequel les aspects structurels et fonctionnels peuvent être étudiés. Des études théoriques et empiriques mettent en évidence de fortes relations entre les stratégies démographiques, les variations environnementales et la dynamique des populations. Les poissons présentent une grande diversité morphologique qui, à l'échelle du peuplement, tend à augmenter avec la richesse spécifique. Des relations reliant la morphologie et l'écologie, en termes de fonction et de performance dans l'utilisation du milieu, ont été établies, mais dans certains cas, les tendances prédites sont masquées par des biais d'échantillonnage et la flexibilité du comportement en réponse à la variabilité environnementale. Le spectre des stratégies trophiques manifesté par les poissons est large, au niveau inter-spécifique, mais également souvent au niveau intra-spécifique, particulièrement durant l'ontogenèse. La structuration en guildes trophiques est plus complexe dans les peuplements comprenant beaucoup d'espèces. Le partage des ressources alimentaires est généralement perceptible quand les régimes sont examinés sur une période de temps suffisamment longue pour gommer les variations de disponibilité des ressources. La structure et le fonctionnement des réseaux trophiques est variable dans l'espace et dans le temps, et des maillons biotiques et abiotiques peuvent être fortement affectés par les poissons. La gestion des peuplements de poissons au sein d'une biosphère en modification nécessite des informations accrues sur les liens existant entre la diversité biologique et l'habitat, une meilleure connaissance des facteurs qui sont à l'origine des tendances observées, et le développement de modèles qui prédisent les relations entre structure et fonctionnement écologique.

\section{THE STRUCTURAL AND FUNCTIONAL ASPECTS OF FISH DIVERSITY.}

\section{SUMMARY}

This paper briefly reviews relationships between fish biological diversity and ecological function. Local biodiversity and community structure can be viewed in terms of (1) phylogenetic diversity, (2) population structure, (3) life-history strategies, (4) morphological diversity, and (5) trophic diversity. A major challenge is to determine relationships between population/community structure and community/ecosystem function. Phylogenetic community structure is derived from the interaction between colonization, 
extinction, and evolution. Despite the fact that these factors operate over a broad spectrum of spatial and temporal scales, great progress has been achieved in modeling the processes giving rise to genetic/phylogenetic structure. Fish reproductive modes vary greatly, and reproductive guilds and life-history strategies provide frameworks that permit analysis of structure and function. Theory and empirical study reveal strong relationships between life-history, environmental variation, and population dynamics. Fishes display great morphological variation, and at the community-level, morphological diversification tends to increase with species richness. Relationships between morphology, mechanical function, and ecological performance have been established, but in some cases predicted patterns have been obscured by sampling limitations or by behavioral flexibility in response to environmental variation. A great breadth of feeding strategies exists among and often within fish species, particularly during ontogeny. Guild structure is more complex in more species-rich communities, and food partitioning generally emerges when diets are examined over time intervals sufficiently long to bracket fluctuations in resource supplies and demand. Food-web structure and function vary over time and space, and fishes can strongly affect both biotic and abiotic components of aquatic systems. Management of fishes in a changing biosphere requires further documentation of diversity in relation to habitat, improved understanding of factors causing observed patterns, and development of models that predict relationships between the elements of ecological structure and function.

\section{RELATING TAXONOMIC DIVERSITY TO ECOLOGICAL DIVERSITY}

There is no simple formulation for the relationship between taxonomic diversity and ecological diversity. Indeed, both taxonomic diversity and ecological diversity can be defined in different ways. Obviously one can view biodiversity at different levels of the taxonomic hierarchy (=presumptive phylogeny) that range from biological kingdoms to individual organisms. Ecology has a long history of emphasizing species as the units of analysis, although recent research reveals greater observance of the influence of higher (e.g., guilds, SIMBERLOFF \& DAYAN, 1991 ; trophospecies, YODZIS, 1993) and lower (e.g., metapopulations, HANSKI \& GILPIN, 1991 ; individual differences, DEANGELIS \& GROSS, 1992) levels of taxonomic resolution on ecological phenomena. The more challenging problem is to identify patterns and processes that directly link taxonomic diversity to ecological structures and functions. To a very great extent, this represents the primary challenge of modern conservation biology. How much biodiversity should be maintained, and at what level of taxonomic resolution? Biologists have begun debating phylogenetic criteria for establishing conservation priorities based on an evolutionary perspective (DIZON et al., 1992 ; VANE-WRIGHT et al., 1991), however, to date, this debate has scarcely been extended to phylogenetic criteria based on the perspective of ecological structure and function (WALKER, 1992). Currently, there is great interest in the maintenance of ecosystem integrity based on species as functional taxonomic units. Given that biological diversity is declining and conservation resources are inadequate, should we develop conceptual frameworks to rank species based on their functional significance and redundancy for ecosytems?

What is taxonomic diversity? Phylogenetic diversity can be viewed at different scales of resolution based on a series of nested clades. At a given scale of phylogenetic resolution, diversity can be calculated by a variety of algorithms to give an index of information content. Most commonly, biologist report the Shannon-Weiner index $\left(H^{\prime}\right)$ based on species as the phylogenetic units. Of course, spatial and temporal scales must be delimited in addition to phylogenetic scale. Phylogenetic patterns often can be predicted over time (following disturbances, in response to episodic recruitment) and across both large (interregional, river zonation, productivity gradients) and small (micro-, meso-habitats) spatial scales.

What is ecological diversity? Like phylogenetic diversity, ecological diversity is viewed across different scales of space, time, and resolution of functional units. Functional ecological units might include ecomorphology, life-history strategies, and trophic guilds. Examination of ecomorphological variation has improved knowledge of the structure and function of fish populations and assemblages (GATZ, 1979 ; KEAST \& WEBB, 1966 ; MEYER, 1990 ; WINEMILLER, 1991). Comparisons of life-history attributes permit not only 
the ordination of ecological syndromes, but also allow determination of demography and responses of populations to environmental variation (BALON, 1975 ; VAN WINKLE et al., 1993 ; WINEMILLER \& ROSE, 1992). Obviously, all organisms must obtain food and avoid becoming the food of another, in order to persist and reproduce. Trophic guilds and food-web structure provide additional means for examining ecological structure and function at the community level (WINEMILLER, 1990 ; WINEMILLER \& PIANKA, 1990). In addition, studies of alternative feeding strategies has revealed ecological structure within fish populations (EHLINGER \& WILSON, 1988 ; HORI, 1991 ; KORNFIELD et al., 1982 ; LIEM, 1980).

The relationship between taxonomic and ecological diversity has been an issue of contention since the beginnings of ecology as a science. The predominant early view, summarized by DOBSHANSKY (1950) and later by ODUM (1969) and MACARTHUR (1972), equated greater species diversity with greater competition and greater ecosystem stability, maturity, and efficiency. MAY (1972) challenged this widely-held view with model results that showed greater species richness actually reduces local stability. May's results were later challenged based on further modeling (DEANGELIS, 1975 ; HAYDON, 1994 ; LAWLOR, 1978 ; NEWMAN \& COHEN, 1986), and alternative definitions of stability were explored (PIMM, 1979). At the same time, equilibrium models of species diversity were joined by models based on successional dynamics following disturbance with maximum species diversity occurring at nonequilibrium population densities (CONNELL, 1978 ; DEANGELIS \& WATERHOUSE, 1987 ; HOLT, 1984 ; HUSTON, 1979 ; SOUSA, 1984). The concept of dynamic species diversity has gained much support in recent years, particularly among those working with vegetation (SHUGART, 1984), intertidal (MENGE \& SUTHERLAND, 1987), reef (SALE, 1978), and stream communities (REICE, 1994 ; RESH et al., 1988). Yet much of the evidence in support of the intermediate disturbance hypothesis and other models of dynamic species diversity is indirect and only implies direct causal mechanisms. Spatial scale is also an important factor that determines taxonomic and ecological diversity (HANSKI, 1982 ; RICKLEFS, 1987 ; WILSON, 1992). The emerging field of macroecology seeks patterns in ecological structure across variable spatial scales (BROWN \& MAUER, 1989). In addition, the role of historical biogeography has not often been explicitly considered when analyzing ecological structure (GORMAN, 1992 ; TAYLOR \& GOTELLI, 1994).

A model that links taxonomic diversity with ecological diversity ultimately must factor in the major influence of history (Fig. 1). The stage for local taxonomic diversity is set by the history of biogeography amd resultant ecological interactions, both biotic and abiotic environmental components (SHMIDA \& WILSON, 1985). Taxonomic diversity then determines the cast of performers to be viewed in the ecological theater of the evolutionary play (HUTCHINSON, 1965). Ecological diversity can be viewed as a series of ecological acts, or conceptual frameworks for viewing structure and function. In actual fact, nature's ecological theater, stages, casts of performers, and acts are unkown to human observers; the ecologist merely scripts different versions based on different operational units and definitions and scales of resolution.

\section{COMPONENTS AND CONSEQUENCES OF ECOLOGICAL STRUCTURE}

In order to persist, all organisms and their descendants must achieve at least some success in the acquisition of nutrition, growth, survival, and reproduction. Therefore, it is quite natural that ecologists attempt to identify structure in factors relating to feeding, habitat utilization, morphology, and reproduction in addition to taxonomic or phylogenetic diversity.

\section{Phylogenetic diversity}

Within a given geographical region, phylogenetic diversity is determined by a combination of historical and contemporary ecological factors (Fig. 1). Phylogenetic affiliations have been documented from scales ranging from assemblages of meso-habitats (MATTHEWS et al., 1994) in local communities to regional ichthyofaunas (ROBERTS, 1975 ; LEVEQUE et al., 1990, LUNDBERG, 1993). At the local scale, contemporary ecological factors, rather than historical factors, are of primary interest, although barriers to local dispersal have played a key role in some cases (ENDLER, 1982). Locally, fish responses to 


\section{Elements of the Ecological Theater}

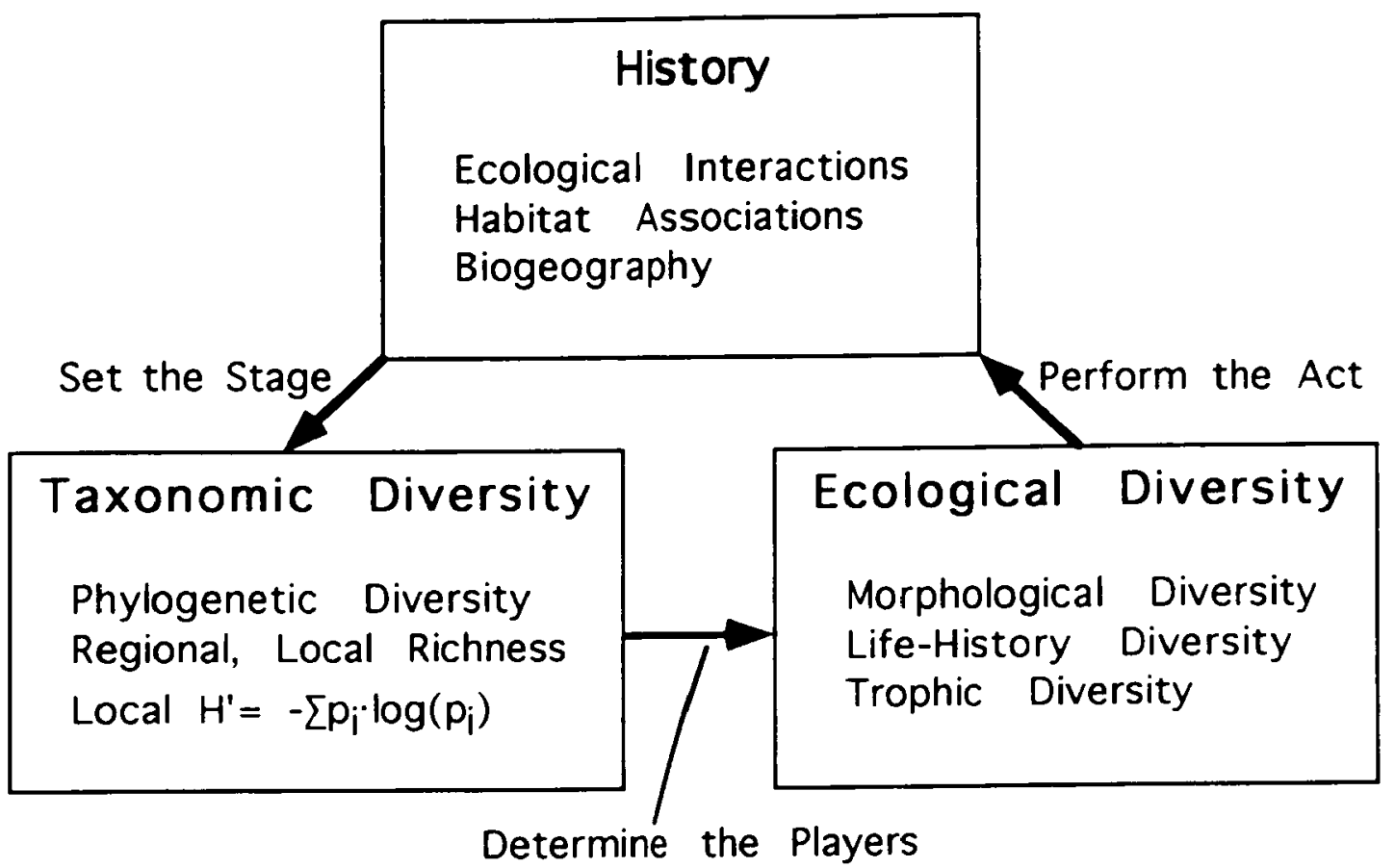

Figure 1 : Le «théâtre écologique»: relations entre les facteurs historiques, taxonomiques et écologiques qui concourent à la mise en place de la biodiversité.

Figure 1 : Elements of the "ecological theater»: causal relationships between historical factors, taxonomy, and ecology that create patterns of biodiversity.

physical and biotic environmental variation results in a subdivision or filtering of regional taxonomic pools into nested subsets at successively smaller spatiotemporal scales (KODRIC-BROWN \& BROWN, 1993 ; MAHON, 1984 ; MATTHEWS, 1986 ; MERONA, 1981 ; TONN \& MAGNUSON, 1982 ; WINEMILLER \& LESIE, 1992).

Fishes provide a rich source of material for the investigation of phylogenetic structure in ecological systems. The evolution of phylogenetic diversity is beyond the scope of this paper. As a group, fishes have much to contribute to the study of phylogenesis. Among vertebrates, freshwater fishes and many demseral and reef-associated marine fishes exhibit strong biogeographical patterns due to limited capabilities to disperse across barriers such as watershed divides, estuaries, and isthmuses (e.g., AVISE, 1992 ; GOLD et al., 1993, MAYDEN, 1992). In the well-known case of cichlid species flocks in African lakes, strong habitat affinities and possibly sexual selection in certain species may result in reproductive isolation within a single lake basin (DOMINEY, 1984 ; MEYER, 1993 ; MEYER et al., 1990 ; WITTE, 1984). Homing behavior by diadromous fishes can result in spatial structuring and genetic divergence within species (MAY et al., 1975).

\section{Population diversity}

Population structure can be viewed in many different ways. The most obvious are the life table attributes: size distribution, age distribution, and sex ratio. Genotypic and phenotypic variation and mating systems provide additional elements of population diversity. Variation in the use of space by individuals yields metapopulation structure and resident/vagrant interactions in territorial systems. 
The consequences of life table variation on population dynamics are well-known, therefore only a brief example of the influence of metapopulation structure on population dynamics is offered here. Many fish populations very obviously are subdivided in space and/or time. Fish populations inhabiting lowland river systems are periodically subdivided into local subunits within floodplain lagoons and later reunited with conspecifics from other subunits during annual floods (JUNK et al., 1989 ; WELCOMME, 1979). Most stream fish populations are subdivided into habitat subunits with variable amounts of migration between them (ELLIOT, 1987 ; FRASER \& CERRI, 1982 ; MATTHEWS et al., 1994 ; SCHLOSSER, 1982). PULLIAM'S (1988) BIDE model may be particularly appropriate for stream fish populations subdivided by mesohabitats. The situation is envisioned in which several pool subunits of a minnow population have a low level of migration between them during periods of normal stream discharge (Fig. 2). Following Pulliam, a source unit has a positive rate of increase with the birth rate (b) exceeding the death rate (d), and a sink unit has a negative rate of increase with $b<d$. Figure 2 depicts a situation in which relatively large minnow densities in large pools containing predators $(\# 2,3)$ are entirely dependent on migration from a smaller subunit in a predator-free pool (\#1). As Pulliam cautioned, interpretations of critical resources and biotic interactions based on field sampling could be strongly skewed without knowledge of source-sink metapopulation dynamics in such situations.

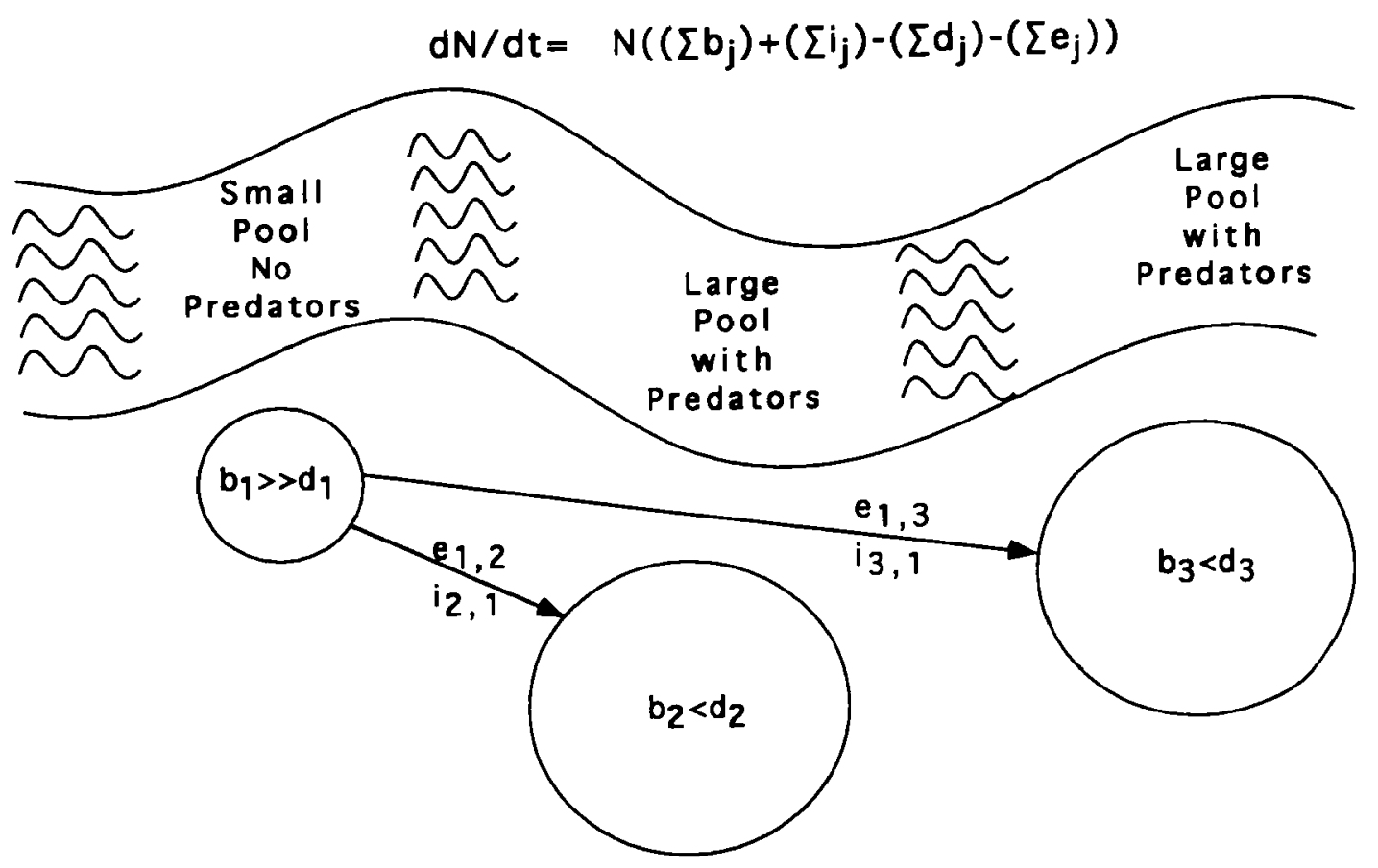

Figure 2 : Description hypothétique de la dynamique d'une métapopulation d'une espèce soumise à la prédation dans les mouilles. L'abondance dans les zones déficitaires $(b<d)$ suite à une forte mortalité par prédation $(2,3)$ dépend de la dynamique dans des petites mouilles sans prédateur.

Figure 2 : Potential metapopulation dynamics of a pool-dwelling stream fish vulnerable to pool-dwelling predators. Abundances of sink subunits in predator-rich pools $(2,3)$ are dependent upon dynamics of a smaller source subunit in a predator-free pool (1). 


\section{Life-history diversity}

Relative to comparable higher taxa, fishes show an awesome array of life-history attributes that provides a basis for identifying ecological structure. Clutch sizes range from a low of one in certain sharks and the coelacanth (Latimeria chulmnae) to over $6 \times 10^{8}$ in the ocean sunfish (Mola mola). Most species have large intraspecific variation in life-history attributes (e.g., size and age at maturity, growth rate, fecundity, egg mass, and longevity). Fish reproductive guilds have been constructed based on spawning habitat, method of egg deposition, and mode of parental care (BALON, 1975). Guilds range from egg-scatterers with external fertilization and group spawning, to ovoviviparity with internal fertilization, to biparental nest guarding. Following Balon's scheme, the physiological ecology of early life stages and parental reproductive strategies largely determine the success of fish populations in a given habitat.

Life-history strategies result from trade-offs among attributes that have either direct or indirect effects on reproduction and fitness. Comparative life-history studies of fishes have identified very similar life-history syndromes (KAWASAKI, 1980; MAHON, 1984 ; PAINE, 1990 ; WINEMILLER, 1989a ; WINEMILLER \& ROSE, 1992 ; WOOTTON, 1984). Three primary life-history strategies define the endpoints of a gradient derived from comparisons of diverse ecological and taxonomic groupings of fishes worldwide (Fig. 3). Periodic-strategists have delayed maturation at intermediate or large sizes, produce large clutches of small eggs, tend to have short reproductive seasons, and tend to have rapid larval and first-year growth rates. Opportunistic-strategists mature early at small sizes, produce small to medium clutches of small eggs, and have long reproductive seasons with multiple spawning bouts. Equilibriumstrategists tend mature at small or medium sizes, produce relatively small clutches of large eggs, have parental care, and often have a protracted reproductive season.

Periodic-strategists receive two benefits from delay maturation and large adult body size: capacity to produce large clutches, and enhanced adult survival during periods of suboptimal environmental conditions, like winter. Fishes with large clutches frequently have synchronous spawning that coincides either with migration into favorable habitats or with favorable periods within the temporal cycle of the environment. Marine fishes cope with largescale spatial heterogeneity in the marine pelagic environment by producing huge numbers of tiny offspring, at least some of which thrive once favorable locations are encountered. On average, larval survival is extremely low among highly fecund fishes in the marine environment, and the average larva perishes during the first 1-2 weeks posthatch. Rapid early growth results from successful exogenous feeding by the few survivors that encounter areas of relatively high resource density.

At higher latitudes, spatiotemporal environmental variation is cyclic. Periodic-type fishes can exploit predictable patterns in time by releasing large numbers of progeny in phase with periods having conditions favorable for larval growth and survival. Selection should favor physiological mechanisms that enhance a fish's ability to detect cues that predict seasonal cycles (e.g., photoperiod, ambient temperature, solute concentrations). In tropical marine pelagic habitats, large-scale variation in space may represent a periodic signal as strong as the seasonal variation at temperate latitudes. Research in physical oceanography has shown patchy distributions for a variety of physical parameters (salinity, temperature), primary production, and zooplankton due to upwellings, gyres, convergence zones, and other currents (e.g., MCCALL, 1990 ; SINCLAIR, 1988).

Many periodic-type fishes are migratory. Anadromous American shad (Alosa sapidissima) show more repeat spawning and devote a greater portion of energy to migration at higher latitudes where environments are more variable and less predictable (LEGGETT \& CARSCADEN, 1978). Anadromous sticklebacks (Gasterosteus aculeatus) have more periodic life-history traits (larger clutches, larger size at maturity) compared with conspecific freshwater populations (SNYDER, 1990). By adopting anadromy, adult fishes can find favorable environments for lanval development and survival. In contrast, the reproductive success of marine broadcast spawners depends upon rates of larval encounters with suitable zones or patches. Massive clutches of small pelagic eggs enhance dispersal capabilities of marine fishes during early life stages. In persistent populations, losses due to settlement in hostile habitats (advection) ultimately are balanced by the survival benefits derived from the passage of some fraction of larval cohorts into suitable regions or habitats. 


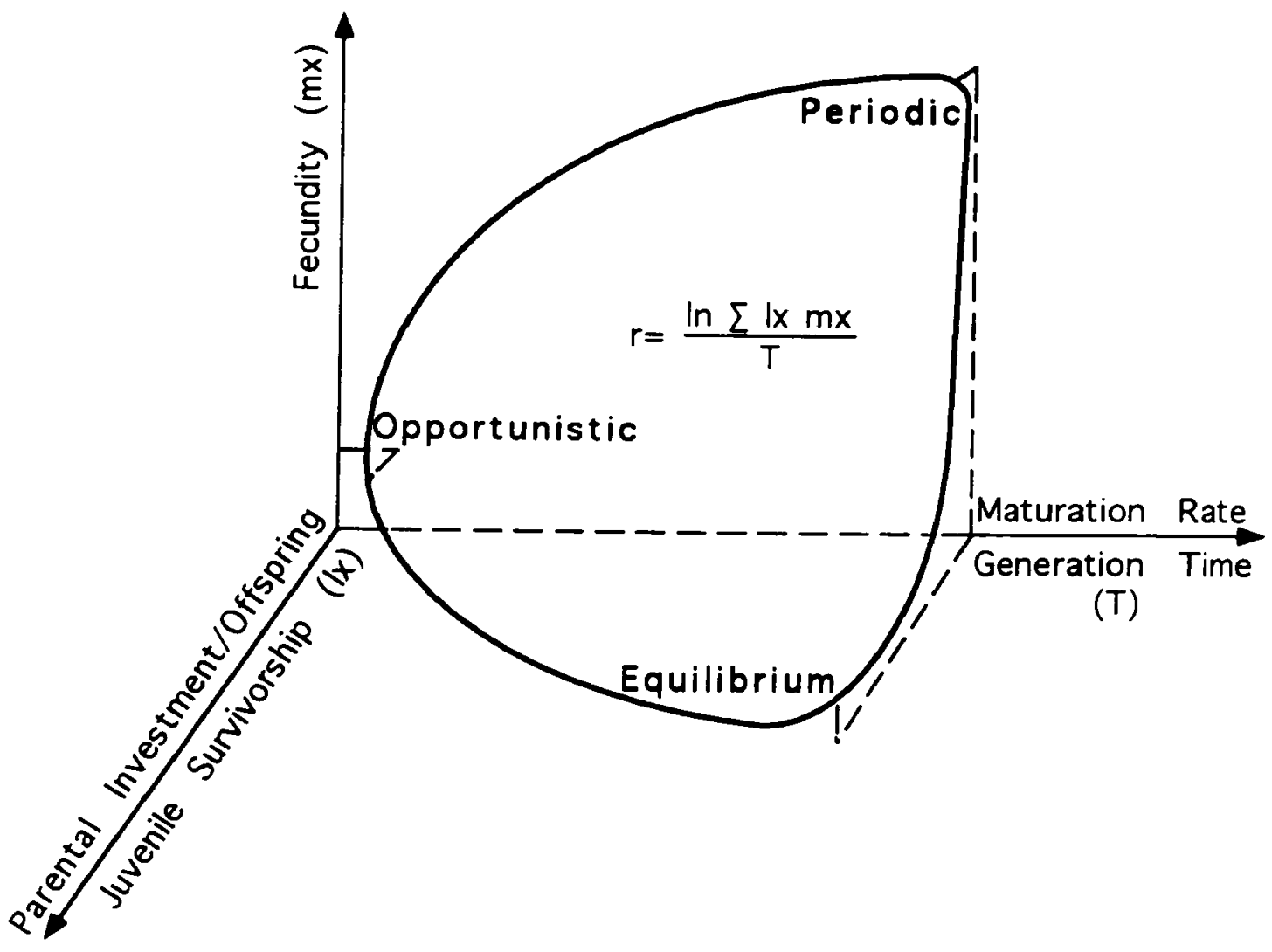

Figure 3 : Surface adaptative prédite par les contraintes existant entre les paramètres démographiques qui conditionnent l'évolution des principales stratégies démographiques observées chez les poissons (d'après WINEMILLER, 1992 ; WINEMILLER et ROSE, 1992).

Figure 3 : Adaptive surface predicted from fundamental constraints in demographic parameter space that result in the evolution of primary life-history strategies observed in fishes (based on WINEMILLER, 1992 ; WINEMILLER and ROSE, 1992).

The opportunistic-strategy is associated with rapid population turn-over rates and a high intrinsic rate of population increase $(r)$. The opportunistic strategy differs from the classical $r$-strategy model (PIANKA, 1970) by having among the smallest rather than largest clutches. By virtue of their small size, the reproductive effort of opportunistic strategists is actually high, despite the fact that absolute clutch size and egg size are small. In these small species, serial spawning sometimes results in an annual clutch biomass that greatly exceeds female body mass. Small fishes with early maturation and frequent spawning are efficient colonizers, and populations can compensate rapidly for continuously high mortality during the adult stage. The opportunistic-strategy is observed in anchovies (Engraulidae), silversides (Atherinidae), killifishes (Cyprinodontidae, Rivuliidae), and livebearing toothcarps (Poeciliidae), fishes that frequently persist in dynamic habitats and often face high predation risk as adults.

The equilibrium-strategy in fishes conforms well to the suite of traits associated with the K-strategy of adaptation to resource-limited or density-dependent environments (PIANKA, 1970). Production of large eggs and parental care results in larger or more 
advanced juveniles at the onset of independent life. Within the North American fish fauna, marine ariid catfishes (oral brooding of a few large eggs, diameter $=16.20 \mathrm{~mm}$ ) and amblyopsid cavefishes (branchial brooding of small clutches of relatively large eggs) exemplify the equilibrium life-history strategy. Sharks, rays, the coelacanth, and other livebearing fishes with long gestation periods and large neonates are extreme cases. Parental care tactics appear to be more highly developed and common in tropical freshwater and reef-dwelling fishes.

Intermediate life-history strategies are recognized within the triangular gradient of life histories. Some of the largest periodic strategists, the sturgeons (Acipenseridae) and paddlefishes (Polyodontidae), have relatively large eggs, thus reducing the theoretical maximum clutch. Salmon and trout have relatively periodic-type attributes, yet they produce relatively small clutches of large eggs. Relative to periodic-strategists with larger clutches and smaller eggs, salmon and trout have evolved a more equilibrium-type strategy of fewer but larger offspring. The growing season at high latitudes may be so short that large fishes are prohibited from adopting a brood-guarding tactic in oligotrophic systems (SHUTER \& POST, 1990). Data from arctic char (Salvelinus alpinus) indicated that the growing season at high latitudes probably constrains age at maturity and the frequency of spawning (DUTIL, 1986). Migration to special spawning habitats and burial of fertilized eggs (brood hiding) by salmon, char, and trout are forms of parental investment that carry large energetic and survival costs in relation to future reproductive effort. A number of mediumsized fishes have seasonal spawning, moderate clutches, and male nest guarding (e.g., ictalurid catfishes and centrarchid sunfishes). Livebearing rockfishes (Scorpaenidae) have large clutches and small eggs. All of these fishes lie between periodic and equilibrium endpoints of the life-history gradient. Small fishes with rapid maturation, small clutches, large eggs, and a short period of male guarding (minnows of the genus Pimephales, madtoms, darters, sticklebacks, pipefishes, and sculpins) lie between the opportunistic and equilibrium endpoints. Similarly, small fishes with seasonal spawning, moderately large clutches, small eggs, and only one or a few bouts of reproduction per season lie between opportunistic and periodic endpoints. Divergent life-history strategies frequently coexist within the same habitats (MAHON, 1984 ; WINEMILLER, 1989a). The ecological niche determines a species' perception of environmental and resource variance; and morphological constraints, including attributes that influence foraging success within different microhabitats, constrain the evolution of life-histories. Table I summarized the principal features and predictions of the triangular-gradient model of life-history evolution.

\section{Life history, population dynamics, and community structure/dynamics}

Fitness can be estimated by either $V_{x}$, the reproductive value of an individual or age class, or by $r$, the intrinsic rate of natural increase of a population or genotype. Each of these fitness measures can be expressed as a function of three demographic components : survivorship, fecundity, and the onset and duration of reproductive life. In the case of reproductive value $\left(V_{x}\right)$,

$$
v_{x}=m_{x}+\sum_{t=x+1}^{\omega}\left(l_{t} m_{t}\right) / l_{x},
$$

where for a stable population $m_{x}$ is age-specific fecundity, $I_{x}$ is age-specific survivorship, and $\omega$ is the last age class of active reproduction. When $x$ is equal to $\alpha$, the age of first reproduction, reproductive value is equivalent to the lifetime expectation of offspring $\left(R_{0}\right)$, and contains survivorship, fecundity, and timing components. The intrinsic rate of population increase can be approximated as

$$
r=\ln \left(R_{0}\right) / T
$$

where $R_{O}$ is the net replacement rate, $T$ is the mean generation time, and

$$
R_{0}=\Sigma l_{x} m_{x}
$$

resulting in

$$
r=\ln \left(\sum I_{x} m_{x}\right) / T \text {. }
$$


Tableau I : Prédictions à propos des facteurs associés avec chacune des stratégies
démographiques situées à l'extrémité des trois gradients modélisés.

Table I : Predictions about the factors associated with endpoint life-history strategies of the trilateral gradient model.

\begin{tabular}{|c|c|c|c|}
\hline & Opportunistic & Periodic & Equilibrium \\
\hline $\begin{array}{l}\text { Demographic factors: } \\
\text { Generation time } \\
\text { (age of maturation) } \\
\text {-Fecundity (clutch size) } \\
\text { Juvenile survivorship } \\
\text { Adult survivorship }\end{array}$ & $\begin{array}{l}\text { small } \\
\text { small- intermediate } \\
\text { low and variable } \\
\text { low and variable }\end{array}$ & $\begin{array}{l}\text { large } \\
\text { large } \\
\text { low and variable } \\
\text { high with low variance }\end{array}$ & $\begin{array}{l}\text { variable } \\
\text { small } \\
\text { high with low variance } \\
\text { high with low variance }\end{array}$ \\
\hline $\begin{array}{l}\text { Physiological factors : } \\
\text { Adult body size } \\
\text { Body size of neonate } \\
\text { or hatchling } \\
\text { Slope of age-fecundity } \\
\text { relationship } \\
\text { Longevity }\end{array}$ & $\begin{array}{l}\text { small } \\
\text { small } \\
\text { intermediate } \\
\text { small }\end{array}$ & $\begin{array}{l}\text { large } \\
\text { small } \\
\text { large } \\
\text { intermediate-large }\end{array}$ & $\begin{array}{l}\text { variable across taxa } \\
\text { large } \\
\text { small } \\
\text { intermediate-large }\end{array}$ \\
\hline $\begin{array}{l}\text { Behavioral factors: } \\
\text { Parental care } \\
\text { Duration of reproductive } \\
\text { season } \\
\text { Breeding synchrony } \\
\text { Reproductivebouts } \\
\text { per season }\end{array}$ & $\begin{array}{l}\text { none- little } \\
\text { long } \\
\text { asynchronous } \\
\text { many }\end{array}$ & $\begin{array}{l}\text { none- little } \\
\text { short } \\
\text { synchronous } \\
\text { one- few }\end{array}$ & $\begin{array}{l}\text { much } \\
\text { variable } \\
\text { intermediate } \\
\text { one-few }\end{array}$ \\
\hline $\begin{array}{l}\text { Environmental factors : } \\
\text { Physical environment } \\
\text { Biotic environment } \\
\text { Food resources } \\
\text { Environmental productivity }\end{array}$ & $\begin{array}{l}\text { harsh and unstable } \\
\text { often strong predation } \\
\text { unpredictably varying } \\
\text { variable }\end{array}$ & $\begin{array}{l}\text { cyclic or large patches } \\
\text { density dependence periodic } \\
\text { periodically varying } \\
\text { often high }\end{array}$ & $\begin{array}{l}\text { stable or highly predictable } \\
\text { density-dependence common } \\
\text { relatively stable } \\
\text { often low }\end{array}$ \\
\hline
\end{tabular}

Therefore, growth rate depends directly upon fecundity, timing of reproduction, and survivorship schedule. Averaged over many generations, the three parameters must balance, or populations decline to extinction or grow to precariously high densities and crash.

Three primary life-history strategies of fishes result from trade-offs among age of maturation ( $\alpha$ positively correlated with T), fecundity, and survivorship (Fig. 3 ). The periodic-strategy corresponds to high values on fecundity and age at maturity axes (a correlate of population turnover rate) and low values on the juvenile survivorship axis. The opportunistic-strategy of high $r$ via rapid maturation corresponds to low values on all three axes. The equilibrium-strategy corresponds to low values on the fecundity axis and high values on the age of maturity and juvenile survivorship axes.

The equilibrium strategy should be favored in density-dependent and resourcelimited settings, and this may be why it is more prevalent among tropical freshwater and reef fish communities. The equilibrium strategies and niche specializations of African rift lake cichlids are well known. In the marine environment, parental care is most frequently associated with small benthic fishes (pipefishes, seahorses, eelpouts, some gobies) and predatory elassmobranchs. Populations of some brood-tending darters (Etheostoma spp.) and madtoms (Noturus spp.) are probably limited by the availability of refuges in stream riffles, especially during periods of reduced stream discharge. Compared with 
opportunistic and periodic strategists, equilibrium strategists generally experience lower temporal variation in population density (Fig. 4) and should conform better to stockrecruit models. Because equilibrium-strategists produce relatively few offspring, early survivorship must be relatively high in order for these populations to persist near some average density. In the case of brood guarding, survivorship during early life stages depends on the condition of adults and nesting habitats. Relatively few equilibrium-type fishes are commercially exploited on a large scale. Several sportfishes exhibit broodguarding and occupy a position intermediate between equilibrium and periodic strategies, including lingcod (Ophiodon elongatus) and the North American blackbasses (Micropterus spp.). In theory, management of exploited equilibrium-type fishes should stress habitat quality/stability and maintenance of healthy adult stocks that promote surplus yields that can be harvested and replaced via natural compensatory mechanisms (VAN WINKLE et al., 1993).

The opportunistic strategy maximizes the intrinsic rate of increase by reducing generation time. Many opportunistic-type fishes are associated with shallow marginal habitats, the kinds of environments that experience the largest and most unpredictable changes on small spatial and temporal scales. Changes in precipitation and temperature induce changes in water depth, substrate characteristics, and productivity in shallow aquatic habitats such as small streams, floodplain swamps, and salt marshes. In the absence of chronic intense predation and resource limitation, opportunistic-type populations quickly rebound from localized disturbances, and these populations probably show large variation in abundance with infrequent strong density-dependence (Fig. 4). Because they tend to be small and often occur in marginal habitats, opportunistic-type fishes are not often exploited commercially. Some important commercial stocks, like menhaden (Brevoortia patronus), are intermediate between opportunistic- and periodicstrategies. Small fishes are often very important food resources for piscivores. Anchovies (Anchoa mitchilli) and silversides (Menidia menidia), may dominate relatively stable habitats, and at the same time suffer high adult mortality from predation. Given their capacity to compensate heavy losses from all stages of lifespans that are typically rather short, a key to the management of opportunistic strategists should be protection from large-scale or chronic perturbations that eliminate important refugia in space and time.

The periodic-strategy maximizes fecundity at the expense of optimizing (reducing) turn-over time (i.e., delayed maturation to achieve sufficient size and to acquire resources) and juvenile survivorship (fecundity increased by producing smaller eggs). Large body size enhances adult survivorship during suboptimal conditions and permits storage of energy and biomass for future reproduction. Perennial reproduction represents a bet-hedging tactic whereby, sooner or later, reproduction coincides with favorable conditions resulting in strong recruitment. Spawning by periodic-type fishes is often annual and synchronous, so that generations are often recognized as discrete annual cohorts that may dominate the population for many years (Fig. 4). Correlations between parental stock densities and densities of recruits have been shown to be negligible in many of these fishes (e.g., marine commercial stocks, HILBORN \& WALTERS, 1992). Recruitment frequently depends on climatic conditions that influence water movement, egg/larval retention zones, productivity, and a host of other environmental factors that determine early growth and survival. Prediction of recruitment by periodic-type species in marine ecosystems requires both knowledge of physical oceanography and the ability to forecast climatic conditions. Because weather cannot be predicted over long intervals, fisheries projections must rely on short-term estimates of juvenile cohort strength, rather than long-term estimates based on parental stocks. For periodic-type fishes, the variance in larval survivorship that serves as input for population projections lies well beyond our ability to measure differences in the field. Since most larvae never recruit into the adult population even under pristine conditions, it follows that some minimum level of spawning must occur each year if strong recruitment is to occur during the exceptional year. Management of exploited populations of long-lived, periodic fishes requires maintenance of some minimum density of adult stocks (so that periodic favorable conditons can be exploited) and the protection of spawning and nursery habitats. Because recruitment is largely determined by unpredictable interannual environmental variation, this minimum density will be impossible to determine with any degree of precision. 

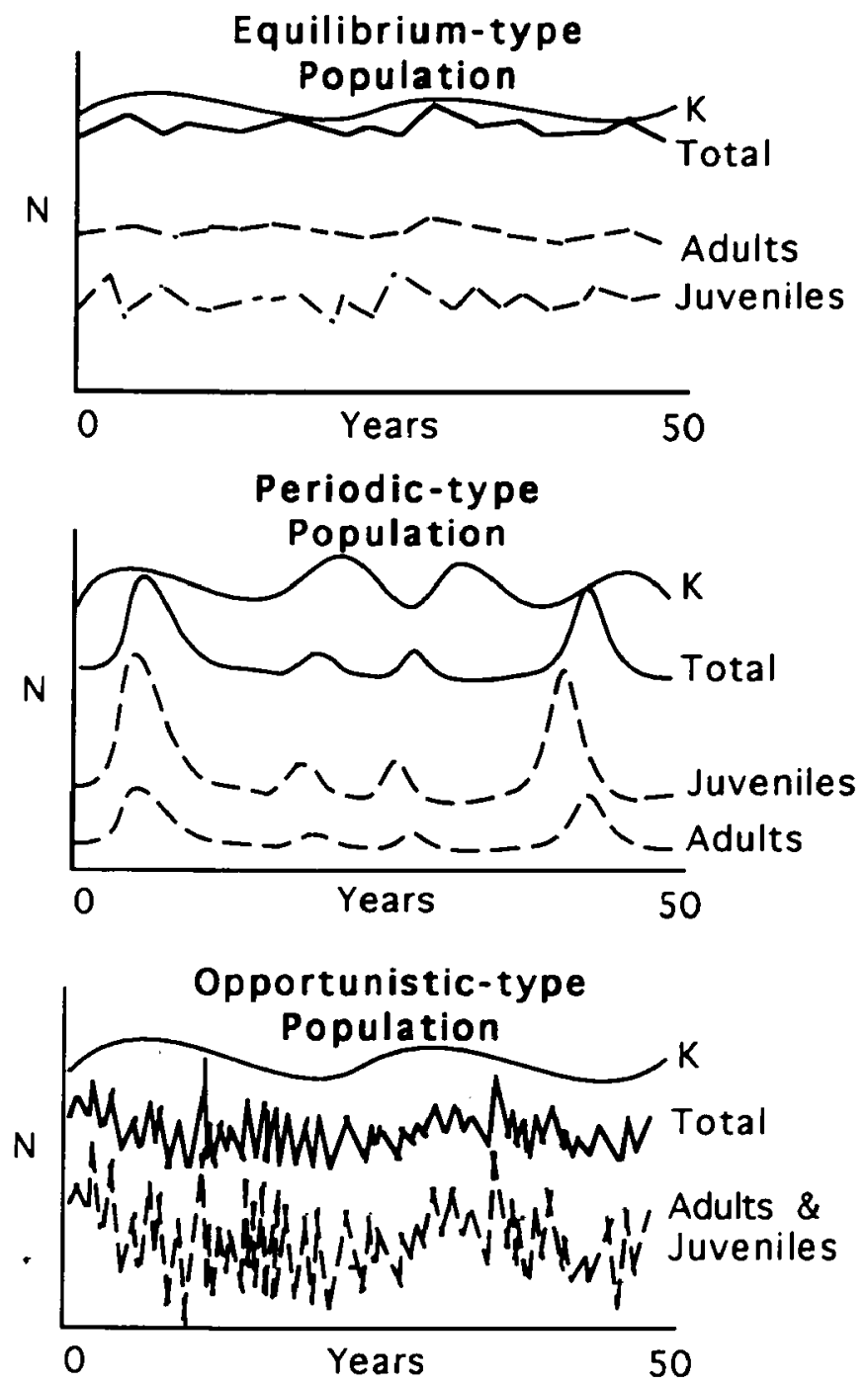

Figure 4 : Relations prédites entre les principales stratégies démographiques et la dynamique des populations. $K$ représente la capacité biotique du milieu. Les espèces utilisant la stratégie d'équilibre sont supposées avoir une population stable à l'état adulte et une faible variabilité inter-annuelle du recrutement. Les espèces appartenant au type périodique sont supposées manifester une grande variabilité inter-annuelle du recrutement, certaines cohortes pouvant dominer numériquement durant plusieurs années suite à des périodes de recrutement très favorables. Une alternance fréquente de mortalité indépendante de la densité, touchant à la fois les adultes et les juvéniles, et de recolonisation rapide est supposée être une caractéristique des espèces du type opportuniste.

Figure 4 : Predicted relationship between primary life-history strategies and population dynamics. $K$ represents envrionmental carrying capacity. Extreme equilibrium-type fishes are presumed to have relatively stable adult populations and low interannual variance recruitment. Dynamics of periodic-type fishes is depicted as having high variance in recuriment, with occasional strong recruitment events that result in annual cohorts that may dominate the population for many years. Opportunistic-type fishes are depicted as experiencing very frequent density-independent mortality of both adults and juveniles, followed by rapid recolonization. 


\section{Morphological diversity}

The great morphologically diversity displayed by fishes can be used as an index of ecological diversity. KEAST \& WEBB (1966) were perhaps the first to do a formal analysis of ecomorphological patterns at the community level. Inspired by the statistical approach employed by FINDLEY (1973) for analysis of bat communities, subsequent fish studies examined morphological patterns within communities, tested additional ecological and evolutionary hypotheses, and refined and extended numerical methods of analysis. Among the first of these was GATZ (1979), who examined patterns of niche partitioning among North American stream fishes based on ecomorphology. Ecomorphological patterns were also investigated for fish communities of Canada and Europe (MAHON, 1984), Borneo (WATSON \& BALON, 1984), Sri Lanka (MOYLE \& SENANAYAKE, 1984 ; WIKRAMANAYAKE, 1990), and Florida (MOTTA et al., in press). LAUDER (1983) integrated ecomorphology with phylogeny to examine evolutionary patterns of niche divergence in North American sunfishes, and WINEMILLER (1991, 1992 ; WINEMILLER et al., in press) examined patterns of ecomorphological convergence and divergence in local assemblages from different biotic regions. Ecomorphological comparisons of faunal structure use morphology as a surrogate for ecological performance and rely heavily of inferences from functional morphology. Whereas faunal studies examine field evidence, functional morphology is performed mosty in the lab. In addition to interfaunal and interspecific comparisons, within-population morphological diversity has been documented for a variety of attributes and species (MEYER, 1990 ; MOODIE, 1972 ; WAINWRIGHT et al., 1991 ; WIMBERGER, 1991).

\section{Ecomorphology and community structure/function}

Morphological diversity increases with species richness on local (GATZ, 1979 ; WATSON \& BALON, 1984 ; Wikarayma and MOYLE \& SENANAYAKE, 1984 ; WINEMILLER, 1990) and regional scales (DOUGLAS, 1987 ; STRAUSS, 1987). At the same time, mean interspecific distances within morphological space did not change greatly over a range of species richnesses and morphological volumes. In a comparison of fluvial swamp/backwater fish assemblages from different biotic regions, morphological space increased with decreasing latitude (Fig. 5). Based on the inference of functional morphology, these ecomorphological patterns are assumed to reflect ecological diversification and niche segregation among coexisting species. WINEMILLER et al. (in press) examined both morphological divergence and diets of cichlid fishes from three biotic regions and concluded that the inference of function from structure was largely justified. Nevertheless, some morphological attributes have greater relevance for ecological function than others, so that the choice of attributes for study makes possible the introduction of bias. In addition, not all investigators have interpreted statistical patterns in the same way. For example, DOUGLAS (1987) interpreted the large morphological volume of sunfishes as indicating many niche generalists, and the smaller morphological volume and smaller interspecific distances of minnows as showing niche diversification in the group. In fact, the centroid represents the generalized ecomorphotype, so that species clustering closely around the centroid represent generalists (WINEMILLER, 1990).

Convergent evolution is a powerful indicator of determinism in ecological processes. Convergence and divergence can be identified by joining the ecomorphology paradigm with phylogenetic information. Strong inferences are possible, even with relatively low resolution phylogenies, provided that the scale of taxonomic/faunal comparison does not exceed the scale of phylogenetic resolution. For example, MARRERO \& WINEMILLER (1993) identified convergent feeding morphology and ecology in weakly electric African mormyriform and South American gymnotiform fishes. WINEMILLER et al. (in press) identified strong patterns of morphological and diet divergence and convergence in three cichlid clades, and interregional faunal convergences among freshwater fish assemblages were apparent even on a global scale (WINEMILLER, 1990).

\section{Trophic diversity}

The wealth of information collected on fish feeding permits the examination of trophic diversity. Whereas most ecologists intuitively appreciate the importance of feeding for population and community structure/function, there is a general lack of appreciation for the 


\section{Distance to Morphological Centroid}

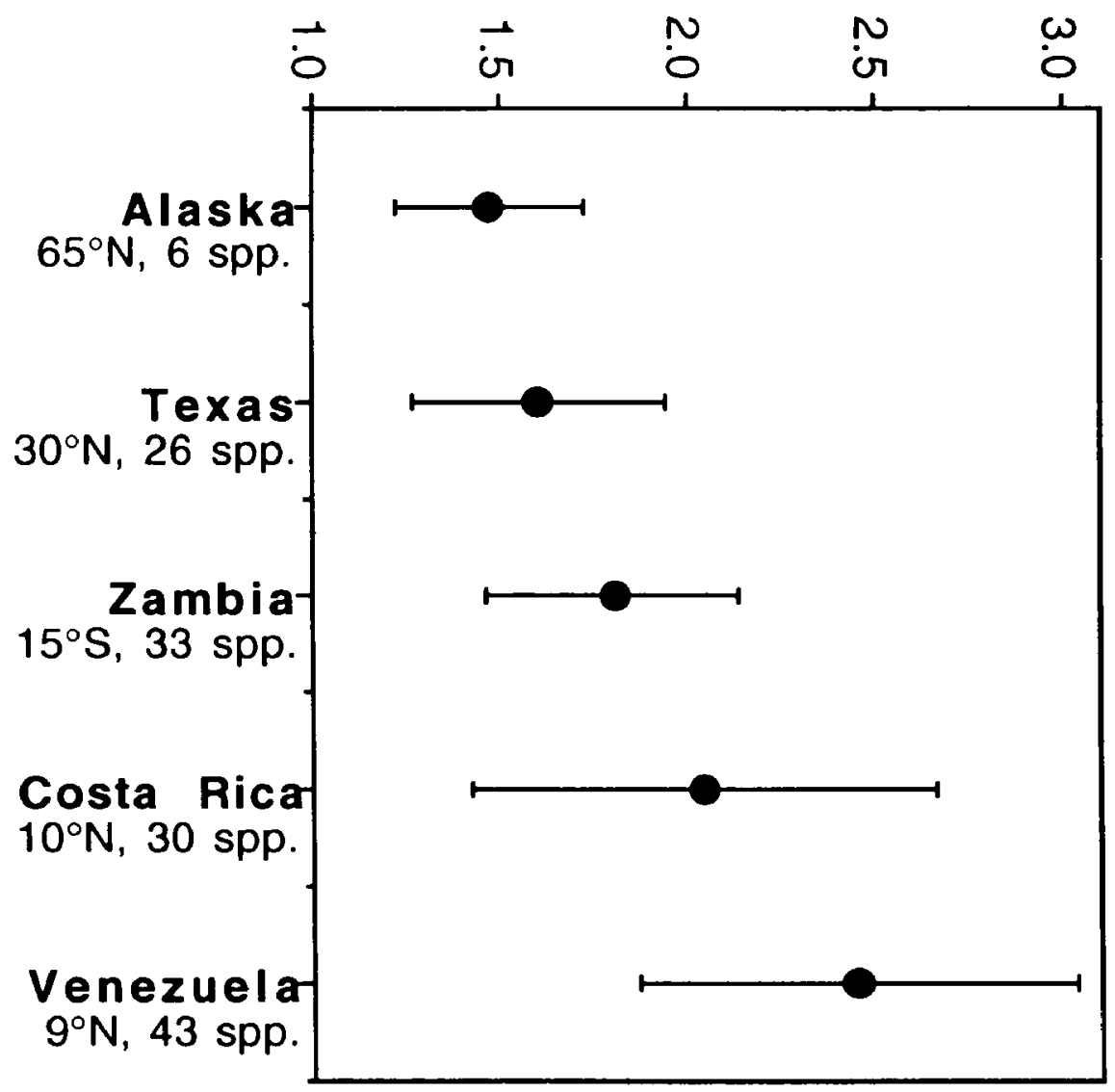

Figure 5 : Diversification morphologique de peuplements de poissons d'eau douce dans des habitats similaires situés à différentes latitudes. La distance moyenne séparant les espèces de chaque assemblage du centroïde calculé à partir des mesures écomorphologiques est représentée, encadrée par l'écart type (d'après WINEMILLER, 1991).

Figure 5 : Morphological diversification in freshwater fish assemblages from similar habitats at different latitudes. Error bars are standard deviations of assemblage centroids derived from ecomorphological data (based on WINEMILLER, 1991).

effects of scale on how we view trophic ecology. The degree of diet specialization is influenced by the level of taxonomic resolution for prey, methods of diet quantification and analysis, and the means of sampling the consumer. Perhaps nowhere are these potential biases more apparent than in the recent literature on food web theory (COHEN et al., 1990, HALL \& RAFFAELLI, 1993 ; PIMM et al., 1992). Food-web laws state that the average number of prey species consumed by predators varies from approximately 2-3 in real food webs (COHEN et al., 1990 ; PIMM et al., 1992 ; MARTINEZ, 1991). To the field investigator these claims appear ludicrous, and major discrepancies in the interpretation of diet breadth can be attributed to the maximum level of aggregation that one is willing to accept as biologically relevant. Theoreticians tend to be more willing to accept highly aggregated diet data than field biologists. On the other hand, field biologists are forced to accept a certain amount of aggregation based on practical limits of measurement precision and accuracy. 
Interspecific trophic diversity has been investigated from the standpoints of assemblage structure and species interactions (e.g., FRYER, 1959 ; GOULDING, 1980 ; GOULDING et al., 1988 ; WINEMILLER \& PIANKA, 1990) and evolutionary divergence within phylogenetic clades (YAMAOKA, 1982 ; WINEMILLER, 1991 ; WINEMILLER et al., in press). Patterns of food resource utilization in fish communities have shown a large degree of diet overlap in most systems (ROSS, 1986), but some studies have demonstrated diet shifts in response to competitors (WERNER, 1977 ; CROWDER, 1986 ; ROBINSON \& WILSON, 1994) or temporally varying resource availability (e.g., ZARET \& RAND, 1971 ; GOULDING, 1980 ; WINEMILLER, 1989b). Development of trophic polymorphisms in response to feeding experience has been demonstrated for several neotropical cichlids (MEYER, 1990; WIMBERGER, 1991) and North American centrarchids (WAINWRIGHT et al., 1991).

\section{Trophic ecology and food-web structure/function}

The net result of trophic diversity within a fish community is the food web. In simple aquatic communities, such as high mountain trout streams, the food web may contain no fish or only a few fishes that consume mostly invertebrate prey. Species-rich communities, contain numerous piscivores and food chains linking fish to fish to fish (Fig. 6 , WINEMILLER, 1990). From a purely trophic standpoint, fishes play several important roles in aquatic and even some terrestrial ecosystems. In their roles as both predators and prey, fishes transfer biomass and energy along pathways throughout the web network (BAIRD \& ULANOWICZ, 1989 ; WINEMILLER, 1990). In addition, fishes frequently move major fractions of community biomass and energy in space, including movement across habitat boundaries. For example, many fishes spawn on flooded plains, where they and their progeny feed and grow before migrating back into the river channel (Fig. 6, JUNK et al., 1989 ; MERONA \& BITTENCOURT, 1993 ; WELCOMME, 1979 ; WINEMILLER, in press). Some of the spawning migrations of large river-dwelling fishes span hundreds of kilometers (BONETTO et al., 1969 ; GOULDING, 1980). Goulding even suggested that migratory fishes of the Amazonian floodplain may be important seed dispersers for numerous tree species. Ecosystem nutrient and detritus budgets can be greatly influenced by egestion and excretion by abundant fishes (DRENNER et al., 1986 ; VANNI, in press ; VANNI \& FINDLAY, 1990 ; VANNI et al., 1990). Nutrient excretion by fishes can have a positive influence on primary production and nutrient mineralization rates (STERNER, 1986). Benthivorous fishes, such as common carp, mechanically disturb sediments and increase sediment suspension, thereby altering nutrient mineralization and water quality.

Predator-prey interactions can have both direct and indirect effects on population densities and community structure and function. Natural predators may depress densities of competitively dominant prey populations and promote the coexistence of greater species richness (PAINE 1966). Alternatively, exotic predators have been shown to depress species richness of prey (ZARET \& PAINE, 1973 ; WITTE et al., 1992). In the case of exotic Nile perch (Lates niloticus) in Lake Victoria, changes in the prey community may have caused localized changes in the nutrients, primary productivity, and water quality (KAUFMAN, 1992). Major shifts in aquatic food webs can even have large effects on adjacent terrestrial communties. The introduction of shrimp (Mysis relicta) into lakes resulted in reductions in salmon with ultimately negative effects on bears and eagles (SPENCER et al., 1991). There is increasing evidence that fishes as predators indirectly influence components of the lower food web via the direct effects of predation transmitted through trophic cascades (CARPENTER, 1988 ; CARPENTER \& KITCHELL, 1988 ; MCQUEEN et al., 1986 ; PARSONS, 1992 ; PERSSON et al., 1988 ; POWER, 1990 ; POWER et al., 1985). Even water quality may be influenced by fish predators at the top of aquatic food webs, although there is some debate about the generality of the phenomenon (DEMELO et al., 1992 ; KITCHELL et al., 1986). Trophic cascades require identification of strong interactors aligned in food chain. Again, level of aggregation plays a critical role. The viability of trophic cascade models (trophic function at the community level) is entirely dependent upon trophic diversity and web structure. Because they determine how populations can respond to different environmental factors and scales of variation, life-history strategies strongly influence food-web structure and function. The population dynamics of an equilibrium-type prey would be very different from that of an opportunistic- or periodic-type prey. Community development after disturbances in floodplain communities can be strongly influenced by 


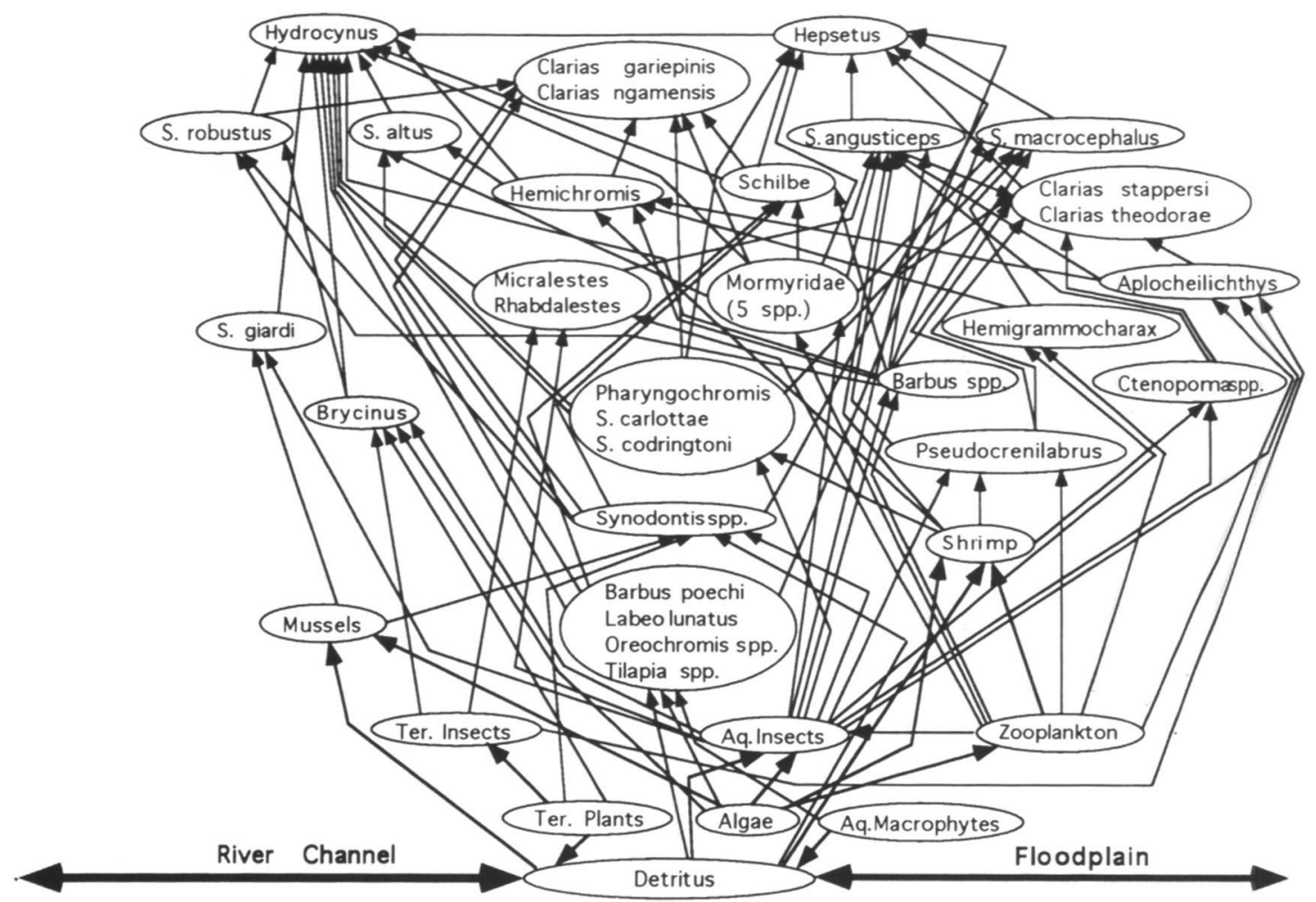

Figure 6 : Position des poissons dans le réseau trophique de la plaine d'inondation du Haut Zambèze. La production primaire est transférée vers les chaînons supérieurs de la chaîne trophique essentiellement par l'intermédiaire des consommateurs situés dans la plaine d'inondation, avant d'atteindre les prédateurs terminaux situés dans le cours principal.

Figure 6 : Fishes as functional components of the Upper Zambezi River floodplain food web. Basal production is transfered to the upper food web primarily via consumer populations located in floodplain habitats, and most production ultimately enters top components located in the main river channel (based on WINEMILLER, in press).

fish life histories (COPP, 1986 ; DEANGELIS \& WHITE, 1994 ; WINEMILLER, in press). Opportunistic life-histories dominate the early colonizing phase, followed by periodic strategists, and finally equilibrium strategists in the event that the aquatic habitat persists for a long time interval. Domination by periodic and equilibrium strategists is to some extent associated with greater piscivore densities.

\section{Diversity and natural resource management}

Our concepts of biological diversity mold our perceptions and approaches for natural resource management. If the conservation of species diversity is our stated goal, then important assumptions have already been made about our concept of taxonomic diversity, which in turn results in a given set interactions with concepts of ecological diversity. If the goal were the mainentance of some vestige of the natural evolutionary process on earth, then a more complex model of taxonomic diversity is required. If management of economically important fish stocks is our goal, then we must first define those stocks 
(taxonomic diversity) and then focus on elements of ecological diversity that prove to enhance predictive capability. Too often in the past, population model predictions have failed due to insufficient integration between different concepts of ecological diversity. If ecosystem integrity is our goal, then the integration of taxonomic and ecological diversity at different scales is more essential than ever. The mandate for preserving ecosystem integrity is clear, but we have no consensus on the definition of integrity. This lack of consensus can be explained, in part, by the enormous complexity of even the simplest of ecosystems and the fact that ecosystems interact with adjacent systems (i.e., our artificial boundaries leak), but it also can be explained by the adoption of different concepts of diversity. A very common argument for the preservation of species is that they are crucial for the maintenance of a healthy biosphere. A logical extension of this argument is that taxonomic diversity is irrelevant beyond the minimum required for the persistent structure and function of essential ecosystem components. Following this view, functional redundancy might be eliminated as long as system integrity is preserved (WALKER, 1992). Others view the maintenance of taxonomic diversity as the embodiment of ecosystem integrity (ALLAN \& FLECKER, 1993 ; KARR et al., 1986). Following this view, ecosystem integrity is not achieved unless the habitat supports both key functional elements and the maximum taxonomic redundancy characterized in the pristine condition. Currently, ecology has neither the theoretical nor empirical knowledge base to make either determination: How much functional redundancy is nonessential? versus, How much redundancy is natural? Ecology accepts as viable two major schools. On the one hand, taxa can be aggregated into functional units to enhance understanding of higher order biological structure and function (ecosystem models), and on the other, biological interactions impose limiting similarity on coexisting species (competitive exclusion). Perhaps by seeking greater integration among concepts of biological diversity, ecology can achieve some measure of convergence as it undergoes inevitable divergence.

\section{ACKNOWLEDGEMENTS}

I am extremely grateful to P. GAUDIN and the symposium organizing committee for organizing the conference "Fishes and Their Habitat" and for inviting me to present this paper. I thank the Environmental Programme of CNRS for financial assistance that made it possible for me to attend the conference.

\section{REFERENCES}

ALLAN J.D., FLECKER A.S., 1993. Biodiversity conservation in running waters. Bioscience, 43, 32-43.

AVISE J.C., 1992. Molecular population structure and the biogeographic history of a regional fauna : a case history with lessons for conservation. Oikos, 63, 62-76.

BAIRD D., ULANOWICZ R.E., 1989. The seasonal dynamics of the Chesapeake Bay ecosystem. Ecol. Monogr., 59, 329-364.

BALON E.K., 1975. Reproductive guilds of fishes: a proposal and definition. J. Fish. Res. Board Can., 32, 821-864.

BONETTO A., CORDIVIOLA DE YUAN E., OPIGNALBERI C., OLIVIEROS O., 1969. Ciclos hidrológicos del rio Paraná y las poblaciones de peces contenidas en las cuencas temporarias de su valle de inundación. Physis, B. Aires, 29, 213-223.

BROWN J.H., MAUER B.A., 1989. Macroecology: the division of food and space among species on continents. Science, 243, 1145-1150.

CARPENTER S.R., 1988. Transmission of variance through lake food webs. In Carpenter S.R., ed., Complex interactions in lake communities, Springer-Verlag, New York, p. 119-135.

CARPENTER S.R., KITCHELL J.F., 1988. Consumer control of lake productivity. Bioscience, 38, 764-769. 
COHEN J.E., BRIAND F., NEWMAN C.M., 1990. Community food webs: data and theory. Springer-Verlag, New York.

CONNELL J.H., 1978. Diversity in tropical rainforests and coral reefs. Science, 199, $1302-1310$.

COPP G.H., 1989. The habitat diversity and fish reproductive function of floodplain ecosystems. Environ. Biol. Fish., 26, 1-27.

CROWDER L.B., 1986. Ecological and morphological shifts in Lake Michigan fishes: glimpses of the ghost of competition past. Environ. Biol. Fish., 16, 147-157.

DEANGELIS D.L., 1975. Stability and connectance in food web models. Ecology, 56, 238-243.

DEANGELIS D.L., WATERHOUSE J.C., 1987. Equilibrium and nonequilibrium concepts in ecological models. Ecol. Monogr., 57, 1-21.

DEANGELIS D.L., GROSS L.J., editors, 1992. Individual-based models and approaches in ecology: populations, communities, and ecosystems. Routledge, Chapman and Hall, New York, $525 \mathrm{p}$.

DEANGELIS D.L., WHITE P.S., 1994. Ecosystems as products of spatially and temporally varying driving forces, ecological processes, and landscapes : A theoretical perspective. In Davis S.M., Ogden J.C., eds., Everglades: the ecosystem and its restoration. St. Lucie Press, Delray Beach, Florida, p. 9-27.

DEMELO R., FRANCE R., MCQUEEN D.J., 1992. Biomanipulation : hit or myth ? Limnol. Oceanogr., 37, 192-207.

DIZON A.E., LOCKYER C., PERRIN W.F., DEMASTER D.P., SISSON J., 1992. Rethinking the stock concept : a phylogenetic approach. Conserv. Biol., 6, 24-36.

DOBZHANSKY T., 1950. Evolution in the tropics. Amer. Sci., 267, 76-82.

DOMINEY W.J., 1984. Effects of sexual selection and life history on speciation : species flocks in African cichlids and Hawaiian Drosophila. In Echelle A.A., Kornfield I., eds., Evolution of fish species flocks. Univ. Maine Press, Orono, Maine, p. 231-249.

DOUGLAS M.E., 1987. An ecomorphological analysis of niche packing and niche dispersion in stream fish clades. In Matthews W.J., Heins D.C., eds., Community and Evolutionary Ecology of North American Stream Fishes, Univ. Oklahoma Press, Norman, Oklahoma, p. 144-149.

DRENNER R.W., THRELDKELD S.T., MCCRACKEN M.D., 1986. Experimental analysis of the direct and indirect effects of an omnivorous filter-feeding clupeid on plankton community structure. Can. J. Fish. Aquat. Sci., 43, 1935-1945.

DUTIL J.D., 1986. Energetic constraints and spawning interval in the anadromous arctic char (Salvelinus alpinus). Copeia, 945-955.

EHLINGER T.J., WILSON D.S., 1988. Complex foraging polymorphism in bluegill sunfish. Proc. Nat. Acad. Sci. USA, 85, 1878-1882.

ELLIOT J.M., 1987. Spatial distribution and behavioral movements of migratory trout, Salmo trutta, in a Lake District stream. J. Anim. Ecol., 55, 907-922.

ENDLER J.A., 1982. Problems in distinguishing historical from ecological factors in biogeography. Amer. Zool., 22, 441-452.

FINDLEY J.S., 1973. Phenetic packing as a measure of faunal diversity. Amer. Natur., 107, 580-584.

FRASER D.F., CERRI R.D., 1982. Experimental evaluation of predator-prey relationships in a patchy environment : consequences for habitat use in minnows. Ecology, 63, 307-313.

FRYER G., 1959. The trophic interrelationships and ecology of some littoral communities of Lake Nyasa with special reference to the fishes, and a discussion of the evolution of a group of rock-frequenting Cichlidae. Proc. Zool. Soc. Lond., 132, 153-281. 
GATZ A.J., Jr., 1979. Community organization in fishes as indicated by morphological features. Ecology, 60, 711-718.

GOLD J.R., RICHARDSON L.R., KING T.L., 1993. Mitochondrial DNA differentiation and population structure in red drum (Sciaenops ocellatus) from the Gulf of Mexico and Atlantic Ocean. Mar. Biol., 116, 175-185.

GORMAN O.T., 1992. Evolutionary ecology and historical ecology: assembly, structure, and organization of stream fish communities. In Mayden R.L., Systematics, historical ecology, and North American Freshwater fishes. Stanford Univ. Press, Stanford, California, p. 659-690.

GOULDING M., 1980. The fishes and the forest. Univ. California Press, Berkeley, California, $280 \mathrm{p}$.

GOULDING M., CARVALHO M.L., FERREIRA E.G., 1988. Río Negro : rich life in poor water. SPB Academic, The Hague, The Netherlands, $200 \mathrm{p}$.

HALL S.J., RAFFAELLI D.G., 1993. Food webs : theory and reality. In Begon M., Fitter A.H., eds., Advances in Ecological Research, Academic Press, London, p. 187-239.

HANSKI I., 1982. Dynamics of regional distribution: the core and satellite species hypothesis. Oikos, 38, 210-221.

HANSKI I., GILPIN M., 1991. Metapopulation dynamics: brief history and conceptual domain. Biol. J. Linn. Soc., 42, 3-16.

HAYDON D., 1994. Pivotal assumptions determining the relationship between stability and complexity : an analytical synthesis of the stability-complexity debate. Amer. Natur., 144, 14-29.

HILBORN R., WALTERS C.J., 1992. Quantitative fisheries stock assessment: choice, dynamics and uncertainty. Chapman \& Hall, New York, 570 p.

HOLT R.D., 1984. Spatial heterogeneity, indirect interactions, and the coexistence of prey species. Amer. Natur., 124, 377-406.

HORI M., 1991. Feeding relationships among cichlid fishes in Lake Tanganyika: effects of intra- and interspecific variations of feeding behavior on their coexistence. Ecol. Internat. Bull., 19, 89-101.

HUSTON M., 1979. A general hypothesis of species diversity. Amer. Natur., 113, 81-101.

HUTCHINSON G.E., 1965. The ecological theater and the evolutionary play. Yale Univ. Press, New Haven, Connecticut.

JUNK W.J., BAYLEY P.B., SPARKS R.E., 1989. The flood pulse concept in river-floodplain ecosystems. In Dodge D.P., ed., Proceedings of the international large river symposium. Can. Spec. Publ. Fish. Aquat. Sci., 106, 110-127.

KARR J.R., FAUSCH K.D., YANT P.R., 1986. Assessing biological integrity in running waters : a method and its rationale. Spec. Publ. 5. Illinois Natural History Survey, Champaign, Illinois, $29 \mathrm{p}$.

KAUFMAN L., 1992. Catastrophic change in species-rich freshwater ecosystems. Bioscience, 42, 846-858.

KAWASAKI T., 1980. Fundamental relations among the selections of life history in the marine teleosts. Bull. Jap. Soc. Sci. Fisheries, 46, 289-293.

KEAST A., WEBB D., 1966. Mouth and body form relative to feeding ecology in the fish fauna of a small lake, Lake Opinicon, Ontario. J. Fish. Res. Bd. Can., 23, 1845-1874.

KITCHELL J.A., EVANS M.S., SCAVIA D., CROWDER L.B., 1986. Food web regulation of water quality in Lake Michigan and Rehabilitation of Lake Ontariob : the role of nutrient reduction and food web dynamics. Int. Jt. Comm. Rep. Great Lakes Sci. Advisory Bd., 25-33, Ann Arbor, Michigan. 
KODRIC-BROWN A., BROWN J.H., 1993. Highly structured fish communities in Australian desert springs. Ecology, 74, 1847-1855.

KORNFIELD I., SMITH D.C., GAGNON P.S., TAYLOR J.N., 1982. The cichlid fishes of cuatro cienegas, Mexico: direct evidence of conspecificity among distinct trophic morphs. Evolution, 36, 658-664.

LAUDER G.V., 1983. Functional and morphological bases of trophic specialization in sunfishes (Teleostei ; Centrarchidae). J. Morphol., 178, 1-21.

LAWLOR L.R., 1978. A comment on randomly constructed model ecosystems. Amer. Natur., 112, 445-447.

LEGGETT W.C., CARSCADDEN J.E., 1978. Latitudinal variation in reproductive characteristics of American shad (Alosa sapidissima) : evidence for population specific life history strategies in fish. J. Fish. Res. Board Can., 35, 1469-1478.

LEVEQUE C., PAUGY D., TEUGELS G.G., 1990. Faune des poissons d'eaux douces et saumâtres de l'Afrique de l'Ouest, Tome 1. ORSTROM, Inst. Fran. Rech. Sci. Devel. Coop., Paris, 384.

LIEM K.F., 1980. Adaptive significance of intra- and interspecific differences in the feeding repertoires of cichlid fishes. Amer. Zool., 20, 295-314.

LUNDBERG J.G., 1993. African-American freshwater fish clades and continental drift: problems with a paradigm. In Goldblatt P., ed., The biotic relationships between Africa and South America. Yale Univ. Press, Yale, Connecticut, p. 157-199.

MACARTHUR R.H., 1972. Geographical ecology: Patterns in the distribution of species. Harper \& Row, New York, 269 p.

MAHON R., 1984. Divergent structure in fish taxocenes of north temperate streams. Can. J. Fish. Aquat. Sci., 41, 330-350.

MARRERO C., WINEMILLER K.O., 1993. Tube-snouted gymnotiform and mormyriform fishes : convergence of a specialized foraging mode in teleosts. Environ. Biol. Fish., 38, 299-309.

MARTINEZ N.D., 1991. Constant connectance in community food webs. Amer. Natur., 139, 1208-1218.

MATTHEWS W.J., 1986. Fish faunal 'breaks' and stream order in the eastern and central United States. Environ. Biol. Fish., 17, 81-92.

MATTHEWS W.J., HARVEY B.C., POWER M.E., 1994. Spatial and temporal patterns in the fish assemblages of individual pools in a midwestern stream (U.S.A.). Environ. Biol. Fish., 39, 381-397.

MAY R., 1972. Will a large complex system be stable? Nature, 238, 413-414.

MAY B., UTTER F.M., ALLENDORF F.W., 1975. Biochemical genetic variation in pink and chum salmon: inheritance of intraspecies variation and apparent absence of interspecies introgression following massive haybridization of hatchery stocks. J. Hered., 66, 227-232.

MAYDEN R.L., Ed., 1992. Systematics, historical ecology, and North American Freshwater fishes. Stanford Univ. Press, Stanford, California, $969 \mathrm{p}$.

MACCALL A.D., 1990. Dynamic geography of marine fish populations. Univ. of Washington Press, Seattle, $153 \mathrm{p}$.

MCQUEEN D.J., POST J.R., MILLS E.L., 1986. Trophic relationships in freshwater pelagic ecosystems. Can. J. Fish. Aquat. Sci., 43, 1571-1581.

MENGE B.A., SUTHERLAND J.P., 1987. Community regulation: variation in disturbance, competition, and predation in relation to environmental stress and recruitment. Amer. Natur., 130, 730-757. 
MERONA B. DE, 1981. Zonation ichtyologique du bassin du Bandama, Côte d'lvoire. Rev. Hydrobiol. Trop., 14, 63-75.

MERONA B. DE, BITTENCOURT M.M., 1993. Les peuplements de poissons du aLago do Rei», un lac d'inondation d'Amazonie centrale: description générale. Amazonia, 12, 415-441.

MEYER A., 1990. Ecological and evolutionary consequences of trophic polymorphism in Cichlasoma citrinellum (Pisces, Cichlidae). Biol. J. Linn. Soc., 39, 279-299.

MEYER A., 1993. Phylogenetic relationships and evolutionary processes in the east African species flock of cichlid fishes. Tends Ecol. Evol., 8, 279-284.

MEYER A., KOCHER T.D., BASASIBWAKI P., WILSON A.C., 1990. Monophyletic origin of Lake Victoria cichlid fishes suggested by mitochondrial DNA sequences. Nature, 347, 550-553.

MOODIE G.E.E., 1972. Predation, natural selection and adaptation in an unusual threespine stickleback. Heredity, 28, 155-167.

MOTTA P.J., CLIFTON K.B., HERNANDEZ P., EGGOLD B.T., in press. Ecomorphological correlates in ten species of subtropical seagrass fishes: diet and microhabitat utilization. Environ. Biol. Fish.

MOYLE P.B., SENANAYAKE F.R., 1984. Resource partitioning among the fishes of rainforest streams in Sri Lanka. J. Zool., Lond., 202, 195-223.

NEWMAN C.M., COHEN J.E.,. 1986. A stochastic theory of community food webs IV. theory of food chain lengths in large webs. Proc. $R$. Soc. Lond. B, 228, 355-377.

ODUM E.P., 1969. The strategy of ecosystem development. Science, 164, 262-270.

PAINE R.T., 1966. Food web complexity and species diversity. Amer. Natur., 100, 65-76.

PAINE M.D., 1990. Life history tactics of darters (Percidae: Etheostomatiini) and their relationship with body size, reproductive behavior, latitude and rarity. J. Fish. Biol., 37, 473-488.

PARSONS T.R., 1992. The removal of marine predators by fisheries and the impact of trophic structure. Mar. Pollut. Bull., 26, 51-53.

PERSSON L.G., ANDERSSON G., HAMRIN S.F., JOHANSSON L., 1988. Predator regulation and primary production along the productivity gradient of temperate lakes. Patterns and the importance of size structured interactions. J. Fish Biol., 38, 281-293.

PIANKA E.R., 1970. On r- and K-selection. Amer. Natur., 102, 592-597.

PIMM S.L., LAWTON, J.H., COHEN, J.E., 1991. Food web patterns and their consequences. Nature, 350, 669-674.

POWER M.E., 1990. Effects of fish on river food webs. Science, 250, 811-814.

POWER M.E., MATTHEWS W.J., STEWART A.J., 1985. Grazing minnows, piscivorous bass, and stream algae : dynamics of a strong interaction. Ecology, 66, 1448-1456.

PULLIAM H.R., 1988. Sources, sinks, and population regulation. Amer. Natur., 132, 652-661.

REICE S.R., 1994. Nonequilibrium determinants of biological community structure. Amer. Sci., 82, 424-435.

RESH V.H., BROWN A.V., COVICH A.P., GURTZ M.E., LI H.W., MINSHALL G.W., REICE S.R., SHELDON A.L., WALLACE J.B., WISSMAR R.C., 1988. The role of disturbance in stream ecology. J. N. Amer. Benth. Soc., 7, 433-455.

RICKLEFS R.E., 1987. Community diversity: relative roles of local and regional processes. Science, 235, 167-171.

ROBERTS T.R., 1972. Ecology of fishes in the Amazon and Congo basins. Bull. Mus. Comp. Zool., Harvard, 143, 117-147. 
ROBINSON B.W., WILSON D.S., 1994. Character release and displacement in fishes : a neglected literature. Amer. Natur., 144, 596-627.

ROSS S.T., 1986. Resource partitioning in fish assemblages : a review of field studies. Copeia, 352-388.

SALE P.F., 1978. Coexistence of coral reef fishes- a lottery for living space. Environ. Biol. Fish., 3, 84-102.

SCHLOSSER I.J., 1982. Fish community structure and function along two habitat gradients in a headwater stream. Ecol. Monog., 52, 395-414.

SHMIDA A., WILSON M.V., 1985. Biological determinants of species diversity. J. Biogeogr., $12,1-20$.

SHUTER B.J., POST J.R., 1990. Climate, population viability, and the zoogeography of temperate fishes. Trans. Amer. Fish. Soc., 119, 314-336.

SHUGART H.H., 1984. A theory of forest dynamics. Springer-Verlag, New York.

SIMBERLOFF D., DAYAN T., 1991. The guild concept and the structure and function of ecological communities. Ann. Rev. Ecol. Syst., 22, 115-143.

SINCLAIR M., 1988. Marine Populations. Univ. Washington Press, Seattle, Washington.

SNYDER R.J., 1990. Clutch size of anadromous and freshwater threespine sticklebacks: a reassessment. Can. J. Zool., 68, 2027-2030.

SOUSA W.P., 1984. The role of disturbance in natural communities. Ann. Rev. Ecol. Syst., 15, 353-391.

SPENCER C., MCCLELLAND B., STANDORD J., 1991. Shrimp stocking, salmon collapse, and eagle displacement: Cascading interactions in the food web of a large aquatic ecosystem. Bioscience, 41, 14-21.

STERNER R.W., 1986. Herbivores' direct and indirect effects on algal populations. Science, 231, 605-607.

STRAUSS R.E., 1987. The importance of phylogenetic constraints in comparison of morphological structure among fish assemblages. In Matthews W.J., Heins D.C., eds., Community and Evolutionary Ecology of North American Stream Fishes. Univ. Oklahoma Press, Norman, Oklahoma, p. 136-143.

TAYLOR C.M., GOTELLI N.J., 1994. The macroecology of Cyprinella : correlates of phylogeny, body size, and geographical range. Amer. Natur., 144, 549-569.

TONN W.M., MAGNUSON J.JH., 1982. Patterns in the species composition and richness of fish assemblages in Northern Wisconsin lakes. Ecology, 63, 1149-1166.

VANE-WRIGHT R.I., HUMPHREYS C.J., WILLIAMS P.H., 1991. What to protect-systematics and the agony of choice. Biol. Consen., 55, 235-254.

VANNI M.J., in press. Nutrient transport and recycling by consumers in lake food webs : Implications for algal communities. In Polis G.A., Winemiller K.O., eds., Food webs : integration of patterns and dynamics. Chapman and Hall, New York.

VANNI M.J., FINDLAY D.L., 1990. Trophic cascades and phytoplankton community structure. Ecology, 71, 921-937.

VANNI M.J., LUECKE C., KITCHELL J.F., ALLEN Y., TEMTE J., MAGNUSON J.J., 1990. Effects on lower trophic levels of massive fish mortality. Nature, 344, 333-335.

VANWINKLE W., ROSE K.A., WINEMILLER K.O., DEANGELIS D.L., CHRISTENSEN S.W., OTTO R.J., SHUTER B.J., 1993. Linking life history theory, environmental setting, and individual-based modeling to compare responses of different fish species to environmental change. Trans. Amer. Fish. Soc., 122, 459-466. 
WAINWRIGHT P., OSENBERG C.W., MITTELBACH G.G., 1991. Trophic polymorphism in the pumpkinseed sunfish (Lepomis gibbosus Linnaeus): effects of environment on ontogeny. Funct. Ecol., 5, 40-55.

WALKER B.H., 1992. Biodiversity and ecological redundancy. Conserv. Biol., 6, 18-23.

WATSON D.J., BALON E.K., 1984. Ecomorphological analysis of fish taxocenes in rainforest streams of northern Borneo. J. Fish Biol., 25, 371-384.

WELCOMME R.L., 1979. Fisheries ecology of floodplain rivers. Longman, London, England.

WERNER E.E., 1977. Species packing and niche complementarity in three sunfishes. Amer. Natur., 111, 553-578.

WIKRAMANAYAKE E.D., 1990. Ecomorphology and biogeography of a tropical stream fish assemblage: Evolution of assemblage structure. Ecology, 71, 1756-1764.

WILSON, D.S., 1992. Complex interactions in metacommunities, with implications for biodiversity and higher levels of selection. Ecology, 73, 1984-2000.

WIMBERGER P., 1991. Plasticity of jaw and skull morphology in the Neotropical cichlids Geophagus brasiliensis and G. steindachneri. Evolution, 45, 1545-1563.

WINEMILLER K.O., 1989a. Patterns of variation in life history among South American fishes in seasonal environments. Oecologia, 81, 225-241.

WINEMILLER K.O., 1989b. Ontogenetic diet shifts and resource partitioning among piscivorous fishes in the Venezuelan llanos. Env. Biol. Fish., 26, 177-199.

WINEMILLER K.O., 1990. Spatial and temporal variation in tropical fish trophic networks. Ecol. Monogr., 60, 331-367.

WINEMILLER K.O., 1991. Ecomorphological diversification of freshwater fish assemblages from five biotic regions. Ecol. Monogr., 61, 343-365.

WINEMILLER K.O., 1992. Life history strategies and the effectiveness of sexual selection. Oikos, 62, 318-327.

WINEMILLER K.O., in press. Factors driving spatial and temporal variation in aquatic floodplain food webs. In Polis G.A., Winemiller K.O., eds., Food webs : Integration of patterns and dynamics. Chapman and Hall, New York.

WINEMILLER K.O., PIANKA E.R., 1990. Organization in natural assemblages of desert lizards and tropical fishes. Ecol. Monogr., 60, 27-55.

WINEMILLER K.O., LESLIE M., 1992. Fish communities across a complex freshwatermarine ecotone. Environ. Biol. Fish., 34, 29-50.

WINEMILLER K.O., ROSE K.A., 1992. Patterns of life-history diversification in North American fishes: implications for population regulation. Can. J. Fish. Aquat. Sci., 49, 2196-2218.

WINEMILLER K.O., KELSO-WINEMILLER L.C., BRENKERT A.L., in press. Ecological and morphological diversification in fluvial cichlid fishes. Environ. Biol. Fish.

WITTE F., 1984. Ecological differentiation in Lake Victoria haplochromines: comparison of cichlid species flocks in African lakes. In Echelle A.A., Kornfield I., eds., Evolution of Fish Species Flocks, University of Maine at Orono Press, Orono, Maine, p. 155-167.

WITTE F., GOLDSCHMIDT T., WANINK J., VAN OIJEN M., GOUDSWAARD K., WITTEMAAS E., BOUTON N., 1992. The destruction of an endemic species flock: quantitative data on the decline of the haplochromine cichlids of Lake Victoria. Environ. Biol. Fish., 34, 1-28.

WOOTTON R.J., 1984. Introduction : strategies and tactics in fish reproduction. In Potts G.W., Wootton R.J., eds., Fish reproduction. Academic Press, New York, p. 1-12. 
YAMAOKA K., 1982. Morphology and feeding behavior of five species of the genus Petrochromis (Teleostei : Cichlidae). Physiol. Ecol. Japan, 19, 57-75.

YODZIS P., 1993. Environment and trophodiversity. In Ricklefs R.E., Schluter D., eds., Species diversity in ecological communities. Univ. Chicago Press, Chicago, Illinois, p. 26-38.

ZARET T.M., RAND A.S., 1971. Competition in stream fishes: support for the competitive exclusion principle. Ecology, 52, 336-342.

ZARET T.M., PAINE R.T., 1973. Species introduction in a tropical lake. Science, 182, 449-455. 